\title{
UNIVERSAL MEANS
}

\author{
GHEORGHE TOADER
}

Abstract. A mean $U$ is called universal if there exists a constant $p$ such that every mean $M$ be comparable with $p U$. Some known examples of means are analyzed, establishing which of them are universal.

Mathematics subject classification (2000): 26E60.

Key words and phrases: Gini means, Stolarsky means, Muirhead means, Greek means, universal means

\section{REFERENCES}

[1] P. S. BulLen, Handbook of Means and Their Inequalities, Kluwer Acad. Publ., Dordrecht, 2003.

[2] J. SÁNDOR, On certain inequalities for means, J. Math. Anal. Appl. 189 (1995), no. 2, 602-606.

[3] G. TOADER, An exponential mean, "Babes-Bolyai" Univ. Preprint 7 (1988), 51-54.

[4] G. TOADER, S. TOADER, Greek means and the Arithmetic-Geometric Mean, RGMIA Monographs, Victoria University, 2005. (ON-LINE: http://rgmia.vu.edu.au/monographs). 